\title{
Influences of oceanographic and meteorological features on reef fish recruitment in Hawai'i
}

\author{
Helen E. Fox ${ }^{1, *, * *}$, Kelly M. Haisfield ${ }^{1,2, * *}$, Michael S. Brown ${ }^{3}$, Todd C. Stevenson ${ }^{4}$, \\ Brian N. Tissot ${ }^{4}$, William J. Walsh ${ }^{5}$, Ivor D. Williams ${ }^{6}$ \\ ${ }^{1}$ Conservation Science Program, World Wildlife Fund - US, Washington, DC 20037-1132, USA \\ ${ }^{2}$ Sustainable Development and Conservation Biology Program, University of Maryland, College Park, Maryland 20742, USA \\ ${ }^{3}$ Department of Oceanography, Dalhousie University, Halifax, Nova Scotia, Canada, B3H 4R2 \\ ${ }^{4}$ School of Earth and Environmental Sciences, Washington State University, Vancouver, Washington 98686, USA \\ ${ }^{5}$ Division of Aquatic Resources, State of Hawai'i, Honokohau Marina, Kailua-Kona, Hawai'i 96704-8807, USA \\ ${ }^{6}$ Joint Institute for Marine and Atmospheric Research, University of Hawai'i at Manoa, Honolulu, Hawai'i 96822, USA
}

\begin{abstract}
Larval fish recruitment is generally highly variable in space and time, and can significantly influence adult population abundance, density and distribution, as well as community structure in coral reef systems. We investigated relationships between reef fish recruitment (data from the West Hawai'i Aquarium Project) and oceanographic and meteorological variables (measures of eddy presence and frequency, El Niño Southern Oscillation, sea surface temperature, sea surface height, chlorophyll a concentration and rainfall). We compared these variables at different time scales - monthly and annually - to substantiate 1 of 3 possible hypotheses about the relationship between eddies and other oceanographic features and fish recruitment: (1) they are positively correlated, indicating that eddy activity could enhance recruitment; (2) they are negatively correlated, indicating that eddy activity may reduce or inhibit recruitment; and (3) they are not correlated, indicating that eddy activity has no impact on recruitment. We found several potential linkages generally supporting the hypothesis that eddies negatively correlate with fish recruitment. In contrast to previous work, we found significant negative correlations in annual patterns of cold-core mesoscale eddies and young-of-the-year totals on the west coast of the island of Hawai'i. We also investigated time lags between monthly recruitment data and oceanographic data several months earlier, consistent with planktonic larval duration of Zebrasoma flavescens and Ctenochaetus strigosus; these phase shifts also produced negative correlations. Our results are exploratory and are only correlations, and thus do not suggest causation; further exploration is needed to substantiate the possibility that eddies have a negative influence on reef fish recruitment. However, these results do call into question that eddies in west Hawai'i have a positive impact on fish recruitment, a theory that has persisted in the literature for nearly $30 \mathrm{yr}$.
\end{abstract}

KEY WORDS: Mesoscale eddy - Planktonic fish larvae - Fish replenishment area - FRA · Marine protected area $\cdot$ MPA $\cdot$ West Hawai'i Aquarium Project $\cdot$ WHAP

Resale or republication not permitted without written consent of the publisher

\section{INTRODUCTION}

Conservationists and fisheries scientists alike have long had a goal of understanding the dynamics of fish recruitment, which is generally highly variable in space and time. Variation in larval recruitment can significantly influence population abundance, den- sity and distribution, as well as community structure in coral reef systems (Danilowicz 1997). With the increasing use of marine protected areas (MPAs) as a fisheries tool to restore stocks (Worm et al. 2009), there is also increased interest in determining the influence of MPAs relative to other drivers of recruitment variability. 
To address fishery declines and reduce user conflict on the Kohala-Kona-Ka'u (west, leeward) coast of Hawai'i (hereafter, West Hawai'i), 9 fish replenishment areas (FRAs) were established in 1999, closing $27.8 \%$ of the coastline to aquarium fishing, and bringing the total portion of the coastline closed to aquarium fishing (i.e. including existing closed areas) to $35.2 \%$ (Tissot et al. 2004). In parallel, the West Hawai'i Aquarium Project (WHAP) was established to conduct scientific research and monitoring on the effectiveness of this network of MPAs (Tissot et al. 2009). A recent analysis of yellow tang Zebrasoma flavescens, the most heavily harvested species in West Hawai'i, showed a significant increase in juveniles - the main targets of the fishery — within closed areas, and of adults not only within sites closed to fishing but also in 'boundary areas' within $1 \mathrm{~km}$ of MPA borders, whereas densities of juveniles have decreased by $45 \%$ in areas open to fishing (Williams et al. 2009).

Ocean circulation off the West Hawai'i coast is often strongly influenced by the presence of energetic mesoscale (50 to $150 \mathrm{~km}$ in diameter) cyclonic and anticyclonic eddies (Patzert 1969, Lumpkin 1998). Although the mechanisms of formation and propagation of these lee eddies are still a matter of debate (Calil et al. 2008), a key forcing factor, at least of the cyclonic eddies, appears to be the northeast trade winds as they pass between the islands of Maui and Hawai'i (Lumpkin 1998, Dickey et al. 2008). The cold-core, cyclonic eddies are important agents in bringing nutrient-rich deeper waters to the euphotic zone and hence increasing biological activity (Lobel \& Robinson 1986, Seki et al. 2001, Bidigare et al. 2003, Dickey et al. 2008, Kuwahara et al. 2008, Landry et al. 2008, Mahaffey et al. 2008, Rii et al. 2008). This increased nutrient flux, particularly within the oligotrophic subtropical gyre waters of the Hawaiian Islands, could potentially increase survival and subsequent recruitment of coral reef fishes if the eddy persists close to the shore long enough for the fish larvae to complete their development and return to reefs (Limouzy-Paris et al. 1997). In some systems, such as the Kuroshio, eddies are believed to assist larval feeding and transport (Nakata et al. 2000, Kasai et al. 2002), and on the Great Barrier Reef they may affect larval dispersal and recruitment (Wolanski \& Spagnol 2000, Burgess et al. 2007). However, if larvae are concentrated in an eddy along with their predators (Seki et al. 2002) or are entrained in an eddy that moves far offshore, recruitment could potentially decrease (Jones 1968).

In Hawai'i, mesoscale eddies can capture fish larvae from reefs and persist long enough to influence pelagic larval development (Lobel \& Robinson 1988). Some researchers (Lobel \& Robinson 1983, Lobel 1989 , 2011) have suggested that peak reproduction in Hawaiian reef fishes takes place during the months when mesoscale eddies are most likely to occur, although others (Flament et al. 1996) have said the timing of eddies is essentially random.

In addition to mesoscale eddies, other potential influences on fish recruitment and seasonal spawning patterns include water temperature (Balch et al. 1999), rainfall (Friedlander \& Parrish 1998), timing of the spring algal bloom (Platt et al. 2003) and chlorophyll concentrations (Polovina et al. 2001). In this study, we examine possible effects of these variables on larval recruitment, especially whether mesoscale eddy activity is correlated with the reproductive period of fishes, because this may affect future planning and management of MPAs in Hawai'i. Specifically, we investigate whether larval recruitment of coral reef fish in West Hawai'i is correlated with monthly and annual variation in mesoscale eddies, as measured by sea surface temperature (SST) and sea surface height (SSH) identified using satellite data. We used SST and SSH because they are good parameters to use for eddy identification in this region (Polovina \& Howell 2005, J. Polovina pers. comm.) and globally (Fu et al. 2010).

We also explore possible correlations between recruitment and El Niño activity (because fishermen in West Hawai'i have used these events as a predictor of interannual Zebrasoma flavescens recruitment, assumed to be more productive during El Niño events) and between recruitment and productivity (as measured by chlorophyll concentration and rainfall, which would cause increased nutrient runoff from land). We investigate relationships between predictor and response variables to substantiate one of 3 possible hypotheses about the relationship between eddies and other oceanographic features and fish recruitment: (1) they are positively correlated, indicating that eddy activity could enhance recruitment; (2) they are negatively correlated, indicating that eddy activity may reduce or inhibit recruitment; and (3) they are not correlated, indicating that eddy activity has no impact on recruitment.

Variable environmental and oceanographic conditions may influence pelagic larval development, a stage that could last from weeks to months (Victor 1986, Thresher et al. 1989), and food availability (Shima \& Swearer 2009), thus influencing future recruitment several months hence (Sponaugle \& Pinkard 2004, Sponaugle \& Grorud-Covert 2006). Therefore, we also investigated phase shifting the data, i.e. 
examining correlations between fish recruitment data and the preceding months' oceanographic data. Finally, as we were skeptical of the assertion of seasonal peak eddy formation during peak fish reproduction (Lobel \& Robinson 1983, Lobel 1989), we re-examined the data behind those claims. These investigations will further our understanding of how oceanographic and meteorological features influence reef fish recruitment and potentially eliminate misconceptions that have persisted in the literature for nearly $30 \mathrm{yr}$.

\section{MATERIALS AND METHODS}

\section{Data sources}

Postlarval recruits were counted at each of the 23 WHAP survey sites (including 9 FRAs, 5 reference sites [MPAs established prior to creation of the FRA network] and 9 sites open to fishing) (Tissot et al. 2004) (Fig. 1) from March 1999 through November 2010, following the monitoring protocol described by Tissot et al. (2004), which included 4 to 6 visual surveys annually on four $25 \times 4 \mathrm{~m}$ transects at each site.

Eight-day and monthly averages of SST and SSH imagery, sub-scened to 18.5 to $21.5^{\circ} \mathrm{N}, 155$ to $158^{\circ} \mathrm{W}$, were obtained from NOAA's CoastWatch program. SSTs were analyzed from $9 \mathrm{~km}$ resolution Advanced Very High Resolution Radiometer (AVHRR) Pathfinder (January 1999 to December 2002) and AVHRR GAC (January 2002 to December 2010 provided by NOAA OceanWatch-Central Pacific, http://ocean watch.pifsc.noaa.gov/) data. SSHs were analyzed from $30 \mathrm{~km}$ resolution AVISO satellite data (www. aviso.oceanobs.com/) gathered from January 1999 through December 2010 by the TOPEX/Poseidon and Jason-1 altimeters. Global 8-d averages of Pathfinder Version 5.0 (PFV5) night-time all-pixel SST imagery, and the corresponding overall quality flag files, were obtained for January 1999 to December 2009 from the National Oceanographic Data Center (www.nodc. noaa.gov/SatelliteData/pathfinder4km). Chlorophyll a (chl a) concentrations were calculated for the study area from the $4 \mathrm{~km}$ resolution MODIS sensor onboard the NASA Aqua satellite (March 2000 to November 2010; http://modis.gsfc.nasa.gov/). Mean monthly rainfall data (January 1999 to December 2010) were provided by National Weather Service (NWS) weather stations (www.nws.noaa.gov/) on the west coast of Hawai'i: UPLH1, KASH1, WIHH1, HAUH1, KLEH1, KMUH1, PHAH1 and PPLH1 (rainfall gauge summary location maps: www.prh.noaa.gov/hnl/pages/rain_ summary.php), plus Honomalino (W. J. Walsh unpubl.

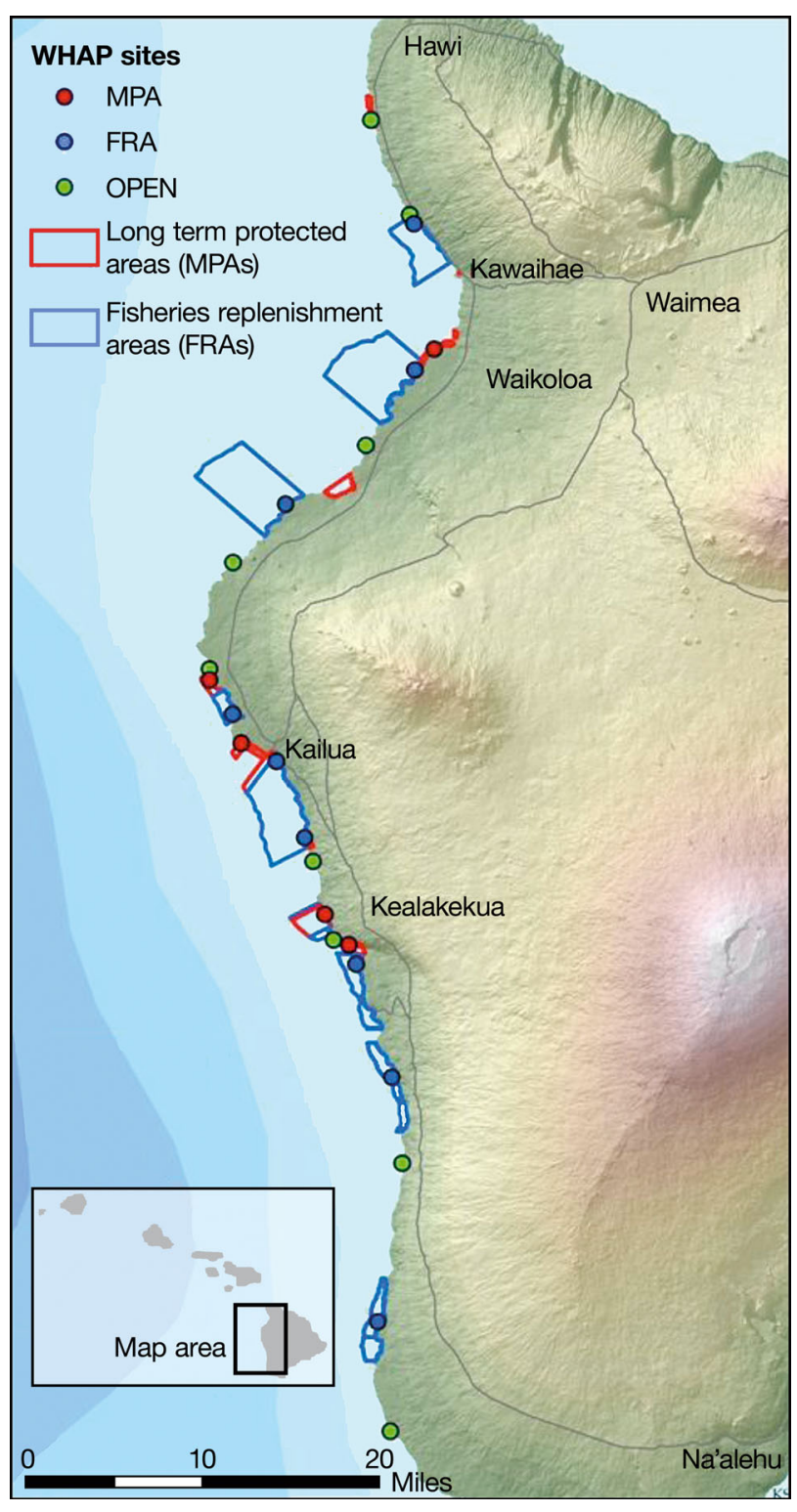

Fig. 1. West Hawai'i Aquarium Project (WHAP) survey sites along the West coast of Hawai'i

data). Lastly, NOAA Climate Prediction Center's Oceanic Niño Index (ONI) was used as a measure of the El Niño Southern Oscillation (ENSO), which is based on SST departures from average in the Niño 3.4 region $\left(5^{\circ} \mathrm{S}\right.$ to $5^{\circ} \mathrm{N}, 120$ to $170^{\circ} \mathrm{W}$ ) (www.cpc.ncep.noaa.gov/ products/analysis_monitoring/ensostuff/ensoyears. shtml).

\section{Annual variation}

To examine variations in annual recruitment and eddy activity, the annual young-of-the-year (YOY) 
totals were calculated for the 5 most abundant species (Zebrasoma flavescens, Ctenochaetus strigosus, Acanthurus nigrofuscus, Chaetodon multicinctus and Thalassoma duperrey), plus those species combined. Because we were interested in recruitment on the scale of the entire management area, all sites and transects were pooled for analysis.

Annual eddy activity was based on a visual determination of eddy presence based on $8 \mathrm{~d}$ images of SST and SSH (sources above). Images were visually interpreted for temperature and altimetry fluctuations (Fig. 2 for color ramp and scale). This process, although time consuming, has been identified as a valid method for identifying eddies (de Souza et al. 2006, D'Alimonte 2009). A clear circular or elliptical SST (e.g. Fig. 2A) or SSH (e.g. Fig 2B) anomaly off the Kona coast persisting in approximately the same location in at least 2 consecutive $8 \mathrm{~d}$ images was recorded as an eddy. The number of $8 \mathrm{~d}$ images per year where eddies were present was recorded as the number of eddy-weeks. SSH images show contour lines (isopleths) of counterclockwise or clockwise direction of water flow, so both cyclonic and anticyclonic eddies were identified, whereas the SST images only show cyclonic (cold-core) eddies clearly. For each data frame in which an eddy was present, we estimated the following: temperature $\left({ }^{\circ} \mathrm{C}\right)$ and height $(\mathrm{cm})$ differential within and outside of the eddy (maximum difference between center and edge of eddy as determined by color differential [SST] or isopleths [SSH]), average diameter of the eddy and nearest distance to shore from the edge of the eddy (in pixels). We also created an expression of the 'influence' of each eddy by multiplying its size (in pixels) by the difference in temperature $\left({ }^{\circ} \mathrm{C}\right)$ or height $(\mathrm{cm})$ from the mean and dividing by the nearest distance to shore (in pixels) to provide quantitative differences between eddies.

Annual averages of chl a concentrations, the annual winter chl a 'algal bloom' (average concentration from November to February) and annual ONI and rainfall averages were calculated from monthly averages for analysis (sources above).

\section{Monthly variation}

To examine finer-scale monthly variation in fish recruitment, we used recruit data from Zebrasoma flavescens and Ctenochaetus strigosus, as they have similar reproductive timing and are the most commonly occurring species, as well as the total of all recruits summed. All sites surveyed within a given month were pooled for analysis. We then calculated moving 3 mo averages to smooth the data. This was necessary to make monthly comparisons, as some months had no WHAP surveys conducted. We recognize the potential risk of transferring uncertainty from the unsmoothed to smoothed data, which could yield smaller $p$-values with narrower confidence intervals.

Several methods were used to estimate monthly eddy activity (but not visual eddy estimation from SST and SSH satellite imagery) and other oceanographic features: standard deviation, mean monthly averages and monthly anomalies.

For standard deviation, the global PFV5 SST and flag files were sub-scened to the region defined above. Regional SST values were quality controlled by masking pixels with a corresponding overall quality flag value of less than 5 (Kilpatrick et al. 2001). The standard deviation of each of these images was computed. Polovina \& Howell (2005) indicate that this measurement can be used as an index of cyclonic eddy activity. The resulting $8 \mathrm{~d}$ time series of SST spatial variance was then converted to a monthly time scale.

For mean monthly averages, we constructed monthly time series of the mean spatial SST, SSH and chl a concentrations, mean monthly rainfall for the west coast of Hawai'i and ONI (based on 3 mo running averages) values using the sources above.

For monthly anomalies, we calculated a monthly time series of anomalies from mean spatial SST, SSH and chl a concentrations. We determined the $12 \mathrm{yr}$ mean for each calendar month of each variable over the entire survey period (1999-2010), and then subtracted this overall mean value from each monthly mean (e.g. January 2005 value - mean January 1999-2010 value = January 2005 anomaly) .

\section{Analyses and phase shifts}

We calculated multiple Spearman's correlations on annual and monthly data to determine the relationships between oceanographic and meteorological features and larval recruitment in Hawai'i (Tables 1 \& 2 for list of variables and annual values). We also explored generalized linear models (GLMs; Poisson distribution and log-link function with overdispersion parameter included) to attempt to identify a more complete picture of how multiple variables are related to reef fish recruitment. For monthly data, several of the oceanographic variables were correlated, so we conducted a principal component analy- 
AVHRR Pathfinder SST from 17 May 2006 to 24 May 2006

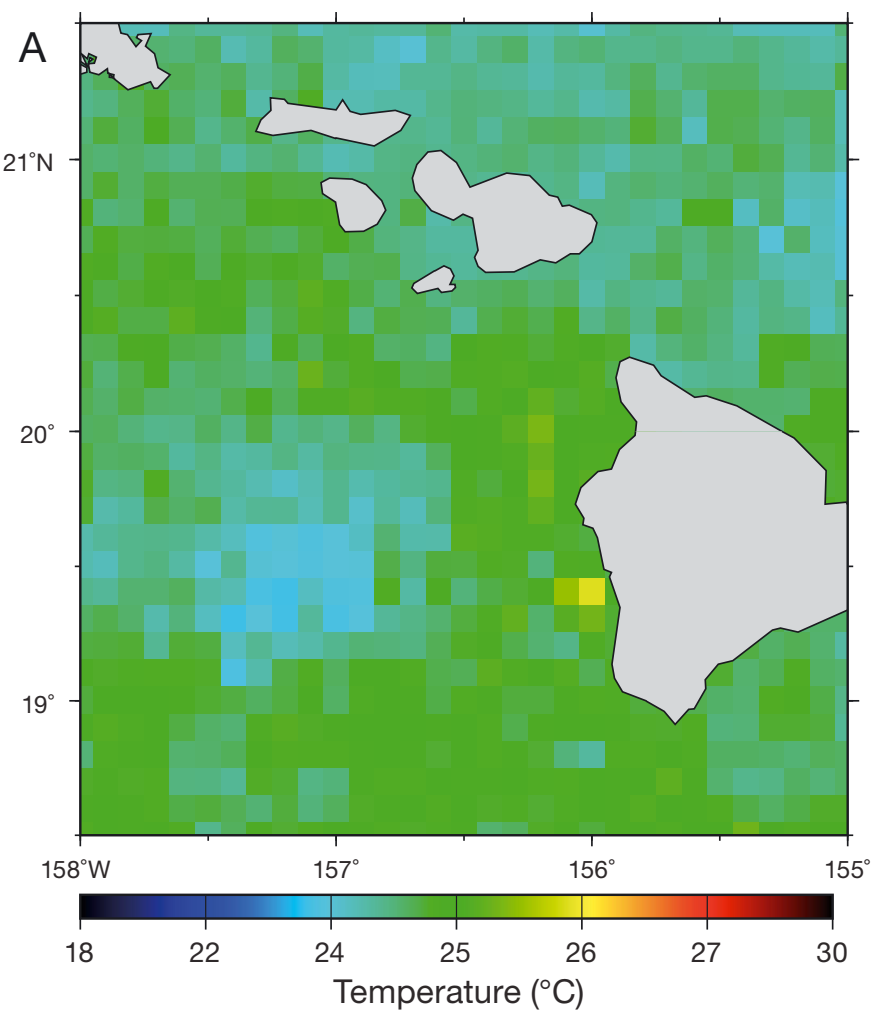

MODIS aqua ocean color 4km for 01 May 2006 to 31 May 2006

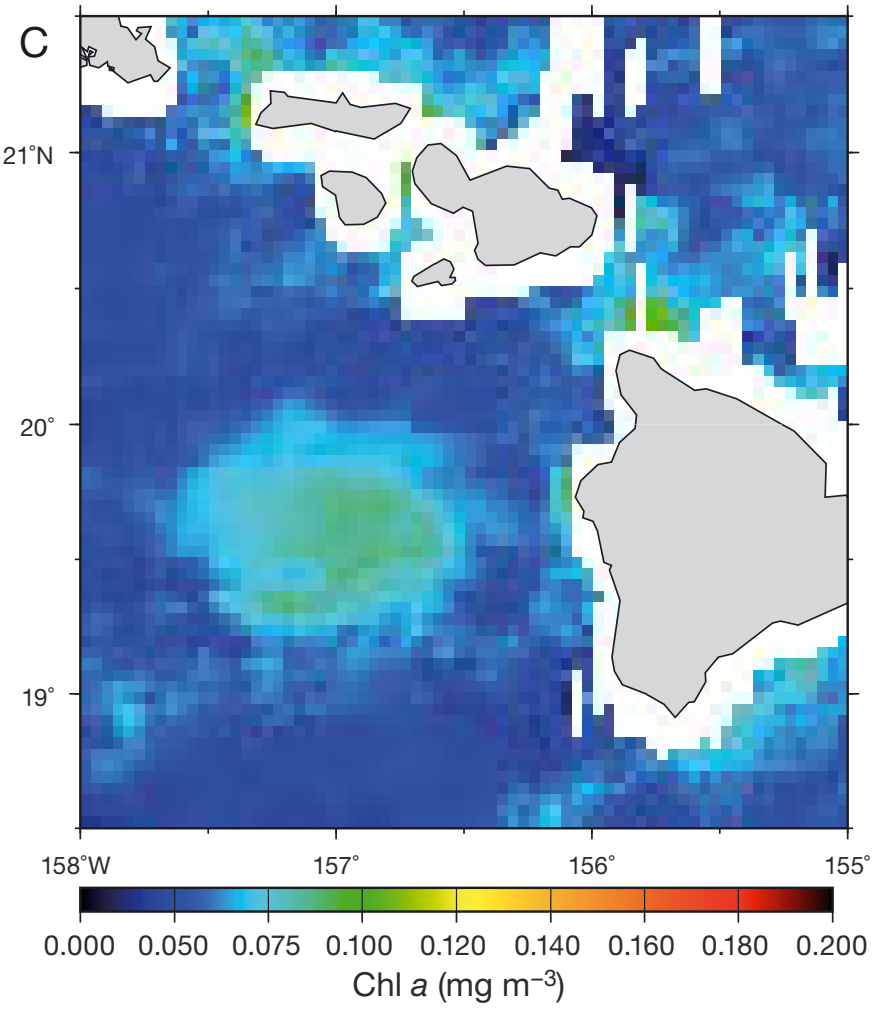

AVISO sea-level altimetry from 18 May 2006 to 24 May 2006

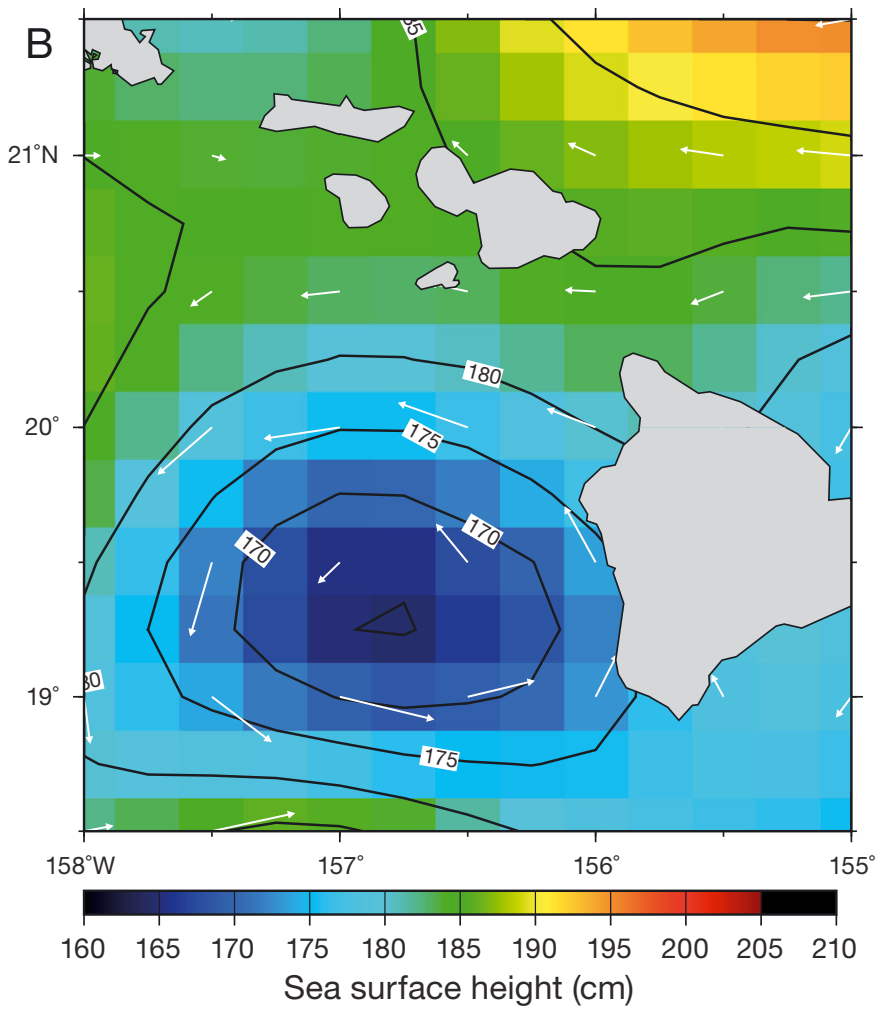

MODIS aqua ocean color 4km for 01 Dec 2004 to 31 Dec 2004

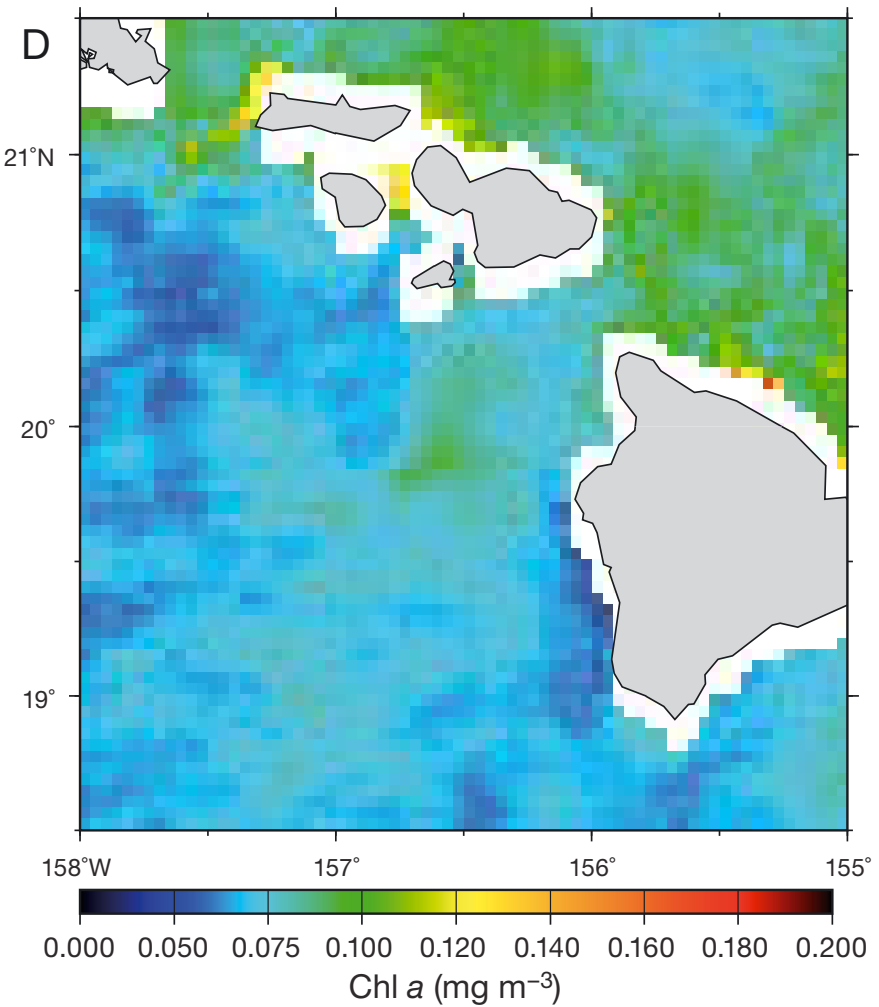

Fig. 2. Representative images showing (A) sea surface temperature (SST), (B) sea surface height (SSH) and (C) chl a, from approximately the same time period in May 2006, and (D) chl a during a winter bloom (December 2004); note that chl a images are monthly whereas the others are weekly 
Table 1. Summary annual data of fish recruitment (young-of-the-year, no. ind. at WHAP survey sites) for the top 5 most abundant species (Zebrasoma flavescens, Ctenochaetus strigosus, Acanthurus nigrofuscus, Chaetodon multicinctus and Thalassoma duperrey), individually and summed

\begin{tabular}{|c|c|c|c|c|c|c|c|c|c|c|c|c|}
\hline Species & 1999 & 2000 & 2001 & 2002 & 2003 & 2004 & 2005 & 2006 & 2007 & 2008 & 2009 & 2010 \\
\hline Z. flavescens & 554 & 405 & 1300 & 4080 & 2678 & 1458 & 2296 & 507 & 1387 & 968 & 4057 & 735 \\
\hline C. strigosus & 388 & 387 & 2089 & 3652 & 1911 & 579 & 2271 & 494 & 1080 & 1103 & 4020 & 570 \\
\hline T. duperrey & 688 & 556 & 570 & 479 & 513 & 266 & 174 & 162 & 309 & 244 & 393 & 298 \\
\hline C. multicinctus & 155 & 41 & 68 & 99 & 524 & 342 & 523 & 207 & 434 & 330 & 396 & 253 \\
\hline A. nigrofuscus & 62 & 35 & 116 & 47 & 563 & 251 & 584 & 252 & 481 & 269 & 759 & 126 \\
\hline Total & 1847 & 1424 & 4144 & 8375 & 6189 & 2896 & 5848 & 1622 & 3691 & 2914 & 9625 & 1982 \\
\hline
\end{tabular}

Table 2. Summary annual data of several measures of eddy activity, and other oceanographic and meterological variables. Means are presented \pm SD. Blank cells indicate years in which data were not available for a given variable. SSH: sea surface height; SST: sea surface temperature

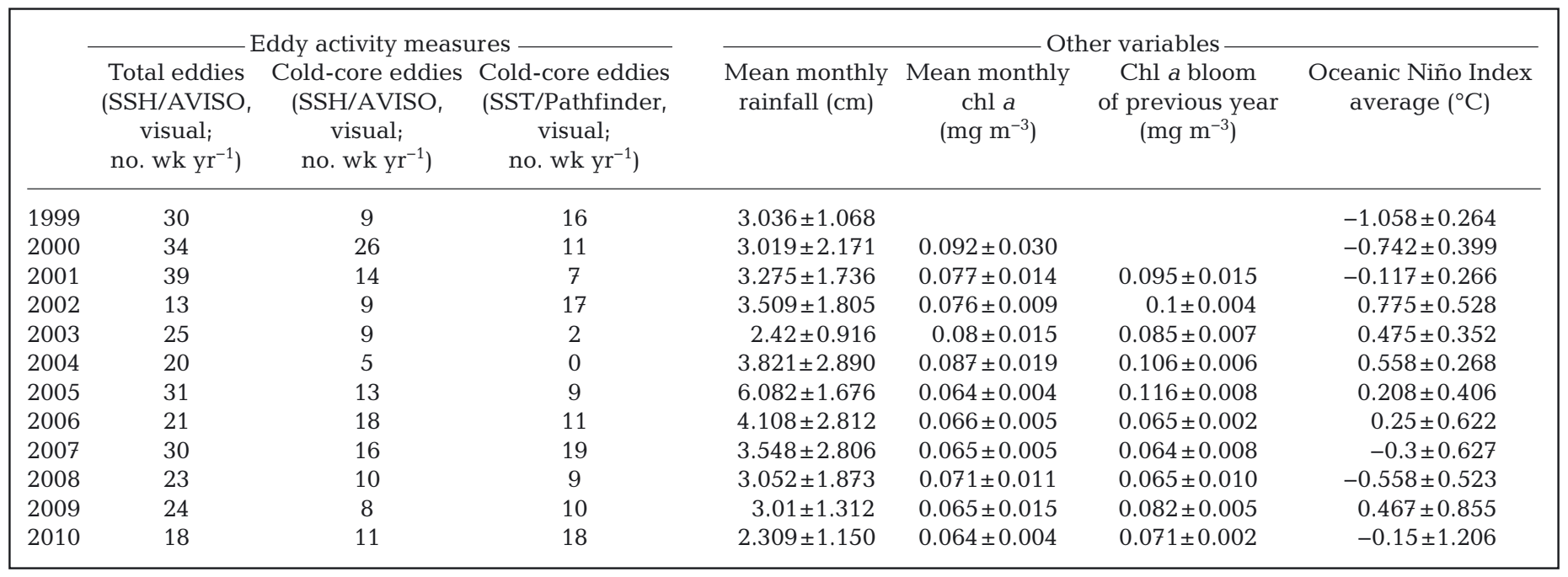

sis (PCA; varimax orthogonal rotation using JMP) to produce a non-correlated subset of variables for use in analysis.

Because reef fish often have a pelagic larval phase lasting up to several months before settling at a recruitment site (Victor 1986, Thresher et al. 1989), we ran additional phase shift analyses to determine possible correlations of oceanographic and meteorological data shifted from 1 mo to 1 yr prior to recruitment data.

\section{Seasonal 'peak eddy formation'?}

In his studies investigating ocean current variability and the spawning season of Hawaiian reef fishes, Lobel $(1989,2011)$ suggested that eddies do have an influence on larval recruitment and posited that peak eddy formation coincided with the peak season of reef fish reproduction, citing data from Patzert (1969). Because our data did not show this pattern, we re-examined the original Patzert data with the inclusion of 2 measures of sampling effort: cruises per season and days spent at sea, which were not accounted for when calculating the number of eddies encountered per season (Lobel \& Robinson 1983, Lobel 1989).

\section{RESULTS}

\section{Annual variation}

We found no statistically significant correlations between recruitment totals of all species combined and the number or intensity of eddies per year or any other oceanographic or meteorological variable (ONI, chl a concentrations, the size of the previous year's algal bloom, or annual mean rainfall) through preliminary analysis of Spearman's correlations with a Bonferroni correction applied to protect $\alpha$ values (Table 3, Fig. 3). Similarly, there were no differences 
Table 3. Spearman's pairwise correlation results of annual data comparing variables with young-of-the-year of the top 5 most abundant species. On an annual time scale, only the Oceanic Niño Index (ONI) is positively correlated with fish recruitment; however with Bonferroni correction $(\alpha=0.0083)$, ONI is not significant

\begin{tabular}{|lrc|}
\hline Variable & $\rho$ & $\mathrm{p}$ \\
\hline Temperature standard deviation $\left({ }^{\circ} \mathrm{C}\right)$ & 0.1273 & 0.7092 \\
Visual cold-core eddies (SSH/AVISO) $>2 \mathrm{wk}$ & -0.4930 & 0.1034 \\
Visual cold-core eddies (SST/Pathfinder) $>2 \mathrm{wk}$ & -0.1926 & 0.5486 \\
Mean monthly chlorophyll $\left(\mathrm{mg} \mathrm{m}^{-3}\right.$ ) & -0.2000 & 0.5554 \\
Mean monthly rainfall $(\mathrm{cm})$ & -0.1049 & 0.7456 \\
Oceanic Niño Index $(\mathrm{ONI})$ average & 0.6014 & 0.0386 \\
\hline
\end{tabular}

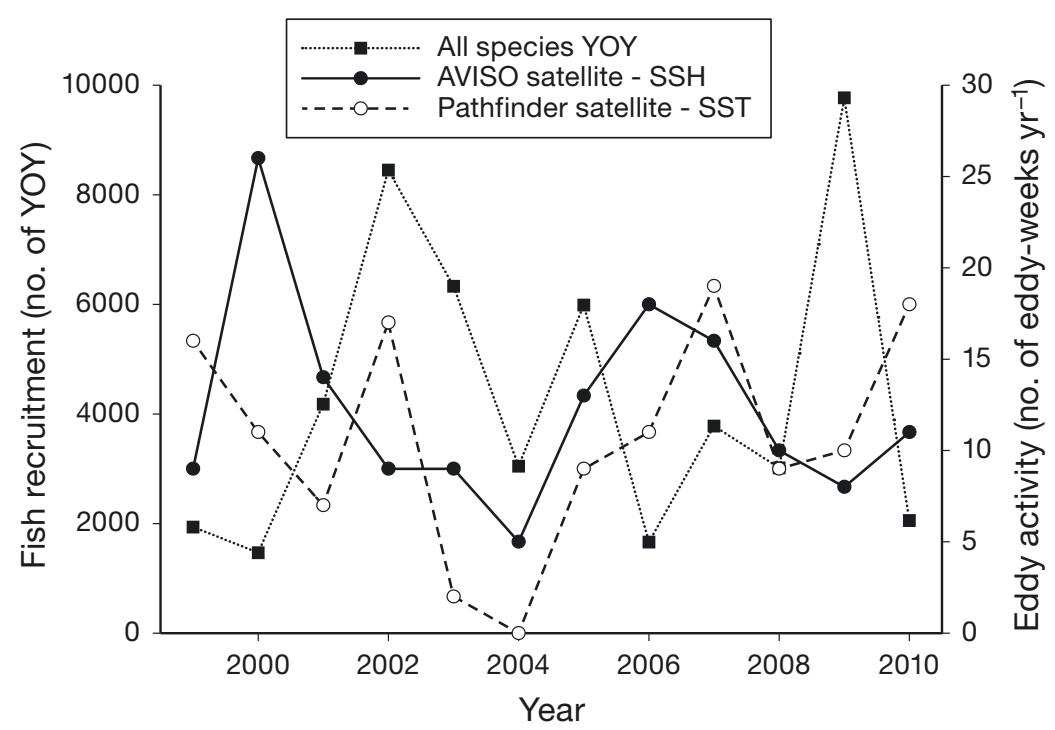

Fig. 3. Relationship between annual young-of-the-year (YOY) totals and number of weeks of eddy persistence per year, as estimated from sea surface height (SSH) and sea surface temperature (SST), determined using AVISO and Pathfinder satellite images, respectively. Only eddies that appeared in 2 or more consecutive $8 \mathrm{~d}$ satellite images were used for analysis (Table 3)

in significance of Spearman's correlations of individual species, with the exception of the Zebrasoma flavescens and ONI relationship ( $\rho=0.75, p=0.0051$ ). However, when multiple variables were used to construct a GLM of YOY recruitment, we found that the number of cold core eddy-weeks per year (as estimated visually by SSH from Aviso satellites) and rainfall were negatively correlated with the top 5 species summed YOY (Table 4).

\section{Monthly variation}

The most abundant juvenile recruits were Zebrasoma flavescens and Ctenochaetus strigosus, ac- counting for over $70 \%$ of all recruits sampled. Peak recruitment for these species was distinctly seasonal, with a peak in June to August (Fig. 4A) (Walsh 1987, Bushnell et al. 2010). In contrast, we found no evidence of a seasonal pattern of eddy activity, although eddy timing and duration was variable (Fig. 4B). We found no significant correlations between monthly reef fish recruitment and eddy activity as measured by standard deviation or mean monthly SSH (Fig. 4, Table 5). Mean monthly SST did show positive correlations with the fish recruitment data, which is unsurprising considering peak recruitment occurs in Hawai'i during the warmer months of the year (Walsh 1987, Bushnell et al. 2010). Monthly chl a concentrations were negatively correlated with recruitment data, driven primarily by the increase in chl $a$, or algal bloom, during the winter months when recruitment is low (Fig. 2D). This negative correlation was not significant when winter months from the chl a data were excluded and Bonferroni correction was applied to account for multiple comparisons. Rainfall and ONI were not correlated with recruitment (Table 5). When factors from our PCA (Table 6) and season were used as explanatory variables in our GLM, Factors 1 and 4, consisting of chl a and temperature related variables, respectively, as well as season had significant effects on variation of monthly recruits. As expected, the summer season had a positive correlation estimate. Factor 4 also had a positive parameter estimate, whereas Factor 1 was negatively related to monthly recruitment.

\section{Phase shifts}

When we explored a variety of phase shifts (up to a $1 \mathrm{yr}$ lag of recruitment behind meteorological variables), recruitment data for all species were significantly negatively correlated with two oceanographic variables ( $\mathrm{SSH}$ and chl a) phase shifted 2 to $5 \mathrm{mo}$ before the recruitment data (Fig. 5, Tables 5 to 7). 
Table 4. Statistical results of annual data. Generalized linear model with summed 5 most abundant species (young-of-theyear) as the response variable, Poisson distribution and log-link function. Results show that increased presence of cold-core eddies and increased rainfall are negatively correlated with fish recruitment when the other listed variables are controlled for. Data for fish recruitment and oceanographic variables were collected from 1999 to 2010 and are pooled to obtain one annual value for each variable per annum

\begin{tabular}{|c|c|c|c|c|}
\hline Model statistics & Estimate & & & \\
\hline Negative log likelihood - full model & 2.16088954 & & & \\
\hline Negative log likelihood - reduced model & 15.587913 & & & \\
\hline Pseudo $\mathrm{R}^{2}$ & 0.86137 & & & \\
\hline$\chi^{2}$ & 26.854 & & & \\
\hline $\mathrm{p}$ & $<0.0001$ & & & \\
\hline df & 6 & & & \\
\hline \multicolumn{5}{|l|}{ Variable statistics } \\
\hline Predictor variable & Estimate & $\mathrm{SE}$ & $\chi^{2}$ & $\mathrm{p}$ \\
\hline Intercept & 8.0969459 & 2.8460176 & 8.6468869 & 0.0033 \\
\hline Temperature standard deviation $\left({ }^{\circ} \mathrm{C}\right)$ & 6.1630868 & 5.1513474 & 1.3863508 & 0.239 \\
\hline Chl a concentration $\left(\mathrm{mg} \mathrm{m}^{-3}\right)$ & -7.523541 & 13.581113 & 0.3114266 & 0.5768 \\
\hline Visual cold-core eddies (SST/Pathfinder) $>2 \mathrm{wk}$ & 0.028004 & 0.0260729 & 1.1249928 & 0.2888 \\
\hline Mean monthly rainfall (cm) & -0.329661 & 0.1607756 & 4.4878259 & 0.0341 \\
\hline Visual cold-core eddies (SSH/AVISO) $>2 \mathrm{wk}$ & -0.078121 & 0.029758 & 8.18341 & 0.0042 \\
\hline
\end{tabular}

\section{Seasonal 'peak eddy formation'?}

We found no indication of increased eddy presence coinciding with the peak season of recruitment (Fig. 6A). Likewise, although the Patzert (1969) data showed more eddies in the spring and summer than in the winter, the researchers spent nearly 3 times as many days at sea, on twice as many cruises during the spring and summer months. Of the 20 cruises included in the report, 8 occurred during the spring months, 8 during the summer and only 4 during the winter. Eddies were encountered on all cruises except one, occurring in the spring. Patzert (1969) recorded 15 eddies from January to May (spring), 14 eddies from June to August (summer) and only 5 eddies from September to December (winter); however, 99, 83 and $33 \mathrm{~d}$ were spent at sea in the region where eddies were detected during the spring, summer and winter, respectively. When accounting for days at sea and number of cruises per season, there was no difference in the number of eddies occurring during each season (days at sea: $\chi^{2}=0.19, \mathrm{p}=0.91, \mathrm{df}=2$; cruises per season: $\chi^{2}=2.00, \mathrm{p}=0.37, \mathrm{df}=2$; Fig. $6 \mathrm{~B}$ )

\section{DISCUSSION}

We found several potential links between eddy activity and fish recruitment, generally supporting the hypothesis that eddies negatively correlate with fish recruitment. Our results show negative correla- tions both between annual fish recruitment and coldcore eddies (Table 4) and between oceanographic variables and fish recruitment 2 to 5 mo later (Fig. 4). Of particular interest is that Zebrasoma flavescens and Ctenochaetus strigosus spend approximately 2 mo in a planktonic larval phase (Eble et al. 2009), which corresponds to the time lag in correlation that we found between oceanographic variables and recruitment (Table 5).

These results are consistent with the hypothesis that eddies may entrain larvae as they move further offshore, reducing overall recruitment, and highlight possible starting points for future exploration of possible mechanisms. Late-larval fish are found in higher concentrations near the periphery of mesoscale Hawai'ian eddies, whereas more passive zooplankton such as fish eggs are found nearer to the center (Lobel \& Robinson 1986), suggesting that those late-larval and early juvenile reef species that are capable of sustained swimming independent of the direction of the current (Leis \& Carson-Ewart 2003) may be attempting to exit the eddy. However, maximum current speeds within a Hawaiian eddy average $150 \mathrm{~cm} \mathrm{~s}^{-1}$ (Lobel \& Robinson 1986), more than double the maximum swimming speed of most reef fish larvae (Fisher 2005). Although larvae can sense nearby reefs using auditory (Wright et al. 2010) or olfactory (Miller-Sims et al. 2011) cues, westward movement of an eddy (Lobel \& Robinson 1986) is likely to take larval fish outside the range of these sensory cues (Radford et al. 2011). 

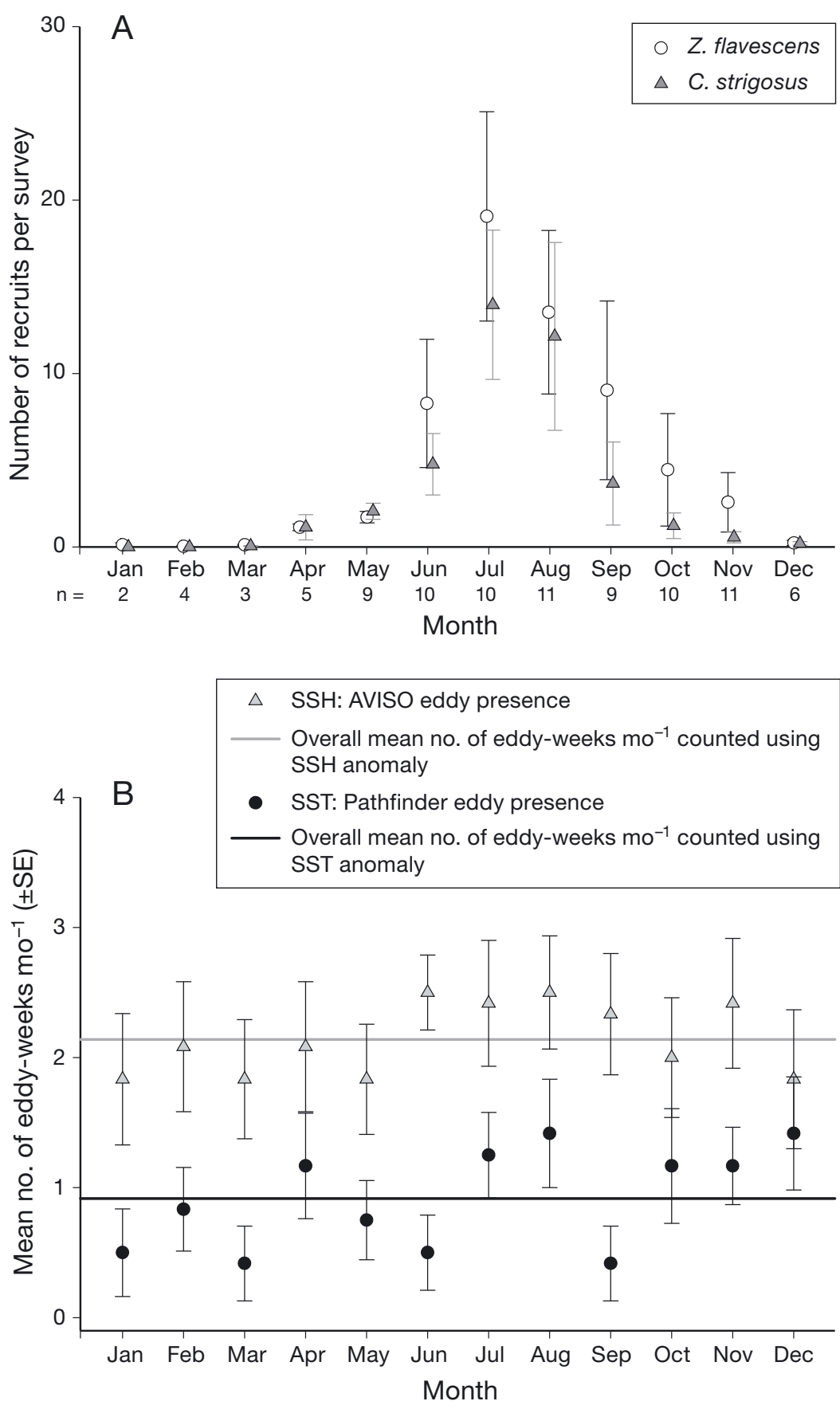

Fig. 4. (A) Recruit data for years 1999-2010 combined for a monthly mean $( \pm \mathrm{SE})$ number of Zebrasoma flavescens and Ctenochaetus strigosus recruits per survey. n: number of years for which surveys were undertaken for a given month; winter and spring surveys were conducted less frequently than summer surveys. (B) Mean $( \pm \mathrm{SE})$ number of eddy-weeks per month for years 1999-2010 determined using satellite images displaying sea surface height (SSH) (AVISO satellite, cold- and warm-core eddies) and sea surface temperature (SST) (Pathfinder satellite, cold-core eddies only). Horizontal lines represent grand mean number of eddies per month determined using satellite images displaying SSH (grey) and SST (black). Monthly Wilcoxon test of eddies SSH: $\chi^{2}=4.54, \mathrm{p}=0.952, \mathrm{df}=11 ; \mathrm{SST}: \chi^{2}=15.70, \mathrm{p}=0.153, \mathrm{df}=11$ determined using satellite images displaying years.
ENSO events are known to influence the recruitment of pelagic fish and some nearshore reef fish in regions closer to the Niño 3.4 region in the Pacific (Meekan et al. 2001, Lehodey et al. 2006, Cheal et al. 2007). Our finding of enhanced Zebrasoma flavescens recruitment during El Niño events is counter to others' descriptions of decreased larval supply during warmer periods (e.g. Lo-Yat et al. 2011). Although the exact mechanism is unknown, El Niño events are known to influence regional trade winds (Cao et al. 2007) and cyclonic activity (Chu \& Wang 1997), which can influence ocean currents and thus recruitment dynamics. El Niño events are also typically associated with a decrease in primary production (Kahru \& Mitchell 2000, Lo-Yat et al. 2011, Park et al. 2011); however, our data showed no correlation between ONI and chl a concentration $\left(\mathrm{R}^{2}<0.0001, \mathrm{p}=\right.$ 0.9717). Further investigation into ENSO and fish recruitment is warranted.

Of course, these results are correlations, and do not indicate causation, and were not conclusive either at annual (Fig. 3, Tables $3 \& 4$ ) or monthly (Tables $5 \& 6$ ) time scales. However, the lack of positive correlations between any of several measures of eddies and fish recruitment in each of several metrics strengthens our argument that previous studies conducted in Hawai'i citing eddies as a positive influence on reef fish recruitment (Lobel \& Robinson 1988, Lobel 1989, 2011) need to be reviewed. Our results suggest that eddies are not the primary force influencing fish recruitment, and may in fact have a negative influence.

Visual identification of an eddy's diameter (and therefore determination of temperature/height differentials and distance to shore) is subjective, as rescaling the color scale of imagery could influence the perceived size of an eddy; however, this 
Table 5. Spearman's pairwise correlation results of monthly data without shifting and shifted by 2 mo comparing variables with average monthly fish recruitment (all species summed, 3 mo moving averages). Sea surface temperature (SST) is positively correlated whereas both chl a variables are negatively correlated with fish recruitment when data are not shifted. When recruitment data are shifted to 2 mo following oceanographic data to account for planktonic larval duration of most common species, SST, sea surface height (SSH), chl $a$ and rainfall are all negatively correlated with fish recruitment. With Bonferroni correction, only p-values $>0.0071$ are significant $\left({ }^{*}\right)$

\begin{tabular}{|c|c|c|c|c|}
\hline \multirow[t]{2}{*}{ Variable } & \multicolumn{2}{|c|}{ - No shift } & \multicolumn{2}{|c|}{ - Shifted $2 \mathrm{mo}$} \\
\hline & $\rho$ & $\mathrm{p}$ & $\rho$ & $\mathrm{p}$ \\
\hline Temperature SD $\left({ }^{\circ} \mathrm{C}\right)$ & 0.1361 & 0.1704 & 0.1536 & 0.1214 \\
\hline Average SST $\left({ }^{\circ} \mathrm{C}\right)$ & 0.3663 & $<0.0001^{*}$ & -0.2861 & $0.0023^{*}$ \\
\hline Average SSH $(\mathrm{cm})$ & -0.1453 & 0.1281 & -0.4425 & $<0.0001^{*}$ \\
\hline Mean monthly chl a $\left(\mathrm{mg} \mathrm{m}^{-3}\right)$ & -0.5055 & $<0.0001^{*}$ & -0.5529 & $<0.0001^{*}$ \\
\hline $\begin{array}{l}\text { Mean monthly chl a } \\
\text { (bloom excluded; } \mathrm{mg} \mathrm{m}^{-3} \text { ) }\end{array}$ & -0.2877 & 0.0157 & -0.3287 & 0.0027 \\
\hline Mean monthly rainfall $(\mathrm{cm})$ & -0.1811 & 0.0572 & -0.2087 & 0.0280 \\
\hline Oceanic Niño Index & 0.1534 & 0.1081 & -0.0018 & 0.9848 \\
\hline
\end{tabular}

ings of others that have, in general, reported unpredictable and highly variable larval recruitment (Caselle \& Warner 1996). Previous studies also suggest the presence of large variability in recruitment rates across biogeographic scales and emphasize the need for an improved understanding of larval responses to ocean circulation in the management and conservation of coastal ecosystems (Broitman et al. 2008). Ecological factors could also explain recruitment variation, including varying source populations (Claisse et al. 2009), post-settlement mortality (Hunt \& Scheibling 1997) or habitat differences (Caselle \& Warner 1996).

Clearly more investigation is needed to determine the causal effects, if any,

process has been identified as a valid method for identifying eddies (de Souza et al. 2006, D'Alimonte 2009). Each set of images had the same color scale for the entire $12 \mathrm{yr}$ period, so the interpretation of the results overall should not be affected. One of our goals was to explore a number of possible avenues for further work, and our results corroborate the find- of oceanographic events on recruitment. If oceanography or meteorology do affect recruitment in later months, understanding that might improve scope for conservation planning, including placement of marine reserves or FRAs, especially in areas with limited recruitment (including Hawai'i; Walsh 1987). For example, because larvae of benthic invertebrates
Table 6. Oceanographic variables grouped into rotated principal components. Principal components analysis performed using JMP, varimax rotation. Number of factors were chosen based on visual inspection of the scree plot and eigenvalues $\geq 1$. These factors correspond to F1 to F4 in Table 7

\begin{tabular}{|c|c|c|}
\hline Factor & Variable & $\begin{array}{l}\text { Rotated } \\
\text { factor loading }\end{array}$ \\
\hline 1 & $\begin{array}{l}\text { Mean monthly chl a concentration } \\
\qquad\left(\mathrm{mg} \mathrm{m}^{-3}\right)\end{array}$ & 0.987 \\
\hline 1 & $\begin{array}{l}\text { Mean monthly chl a concentration - } \\
\text { winter bloom excluded }\left(\mathrm{mg} \mathrm{m}^{-3}\right)\end{array}$ & 0.998 \\
\hline 1 & $\begin{array}{l}\text { Chl a concentration anomaly } \\
\qquad\left(\mathrm{mg} \mathrm{m}^{-3}\right)\end{array}$ & -0.976 \\
\hline 2 & Mean monthly rainfall $(\mathrm{cm})$ & 0.978 \\
\hline 2 & Maui mean monthly rainfall (cm) & 0.856 \\
\hline 2 & Hawaii mean monthly rainfall (cm) & 0.893 \\
\hline 3 & Average $\mathrm{SSH}(\mathrm{cm})$ & -0.891 \\
\hline 3 & Temperature standard deviation $\left({ }^{\circ} \mathrm{C}\right)$ & 0.335 \\
\hline 3 & SSH anomaly $(\mathrm{cm})$ & 0.929 \\
\hline 4 & Oceanic Niño Index & 0.785 \\
\hline 4 & Average SST $\left({ }^{\circ} \mathrm{C}\right)$ & 0.708 \\
\hline 4 & SST anomaly $\left({ }^{\circ} \mathrm{C}\right)$ & -0.806 \\
\hline
\end{tabular}

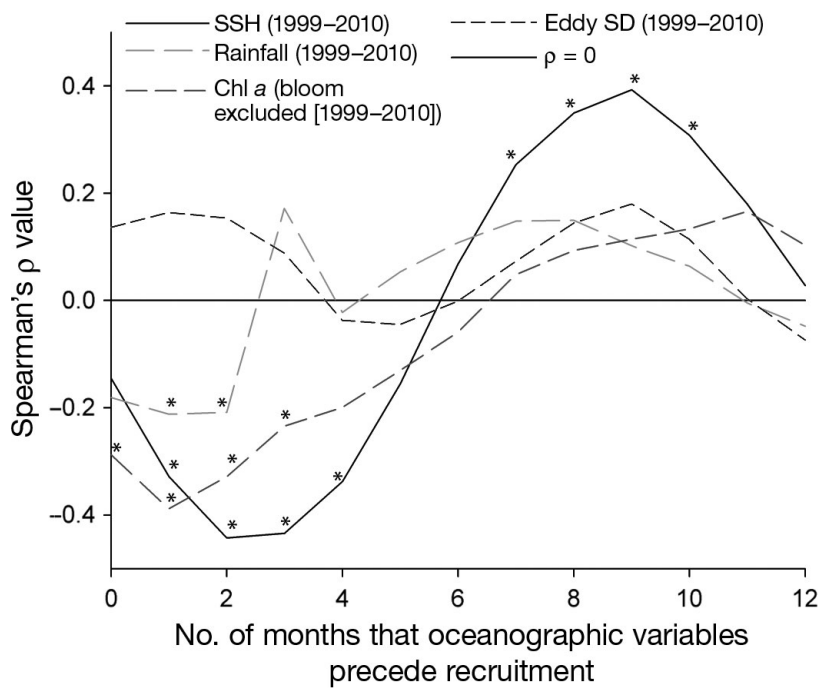

Fig. 5. Spearman's $\rho$ value of correlation between phase shifted data for all fish recruits and different oceanographic variables (years of data collection in parentheses or brackets). All oceanographic data precede recruit data when shifted. Sections of lines denoted by asterisks show significant correlations $(p<0.05)$ when compared with recruitment. Lines above the solid line at $\rho=0$ denote positive correlations, while those below the line designate negative correlations 
Table 7. Statistical results of monthly data. Data for fish recruitment and oceanographic variables were collected from 1999 to 2010 and were pooled to obtain one monthly value for each data set. (A) Generalized linear model, not shifted, with number of recruits of all species as the response variable, Poisson distribution and log-link function. Results show that summer season, chl a anomaly, ONI and SST are positively correlated with recruitment, whereas increased chl a and temperature anomaly are negatively correlated with fish recruitment when other listed variables are controlled for. (B) Generalized linear model, oceanographic features occurring 2 mo prior to recruitment, with number of recruits of all species as the response variable, Poisson distribution and log-link function. Results show that summer season, chl a anomaly, ONI, SST and SSH anomaly are positively correlated with recruitment, whereas increased chl $a_{1}$ SSH and temperature anomaly are negatively correlated with fish recruitment when other listed variables are controlled for. Asterisks indicate variables that are significantly correlated at $\alpha=0.05$

\begin{tabular}{|c|c|c|c|c|}
\hline Predictor variable & Estimate & Standard error & $\chi^{2}$ & $\mathrm{p}$ \\
\hline \multicolumn{5}{|l|}{ (A) Model statistics - no shift } \\
\hline Negative log likelihood - full model & 65.29 & & & \\
\hline Negative log likelihood - reduced model & 128.58 & & & \\
\hline Pseudo $\mathrm{R}^{2}$ & 0.49 & & & \\
\hline$\chi^{2}$ & 126.575 & & & \\
\hline $\mathrm{p}$ & $<0.0001$ & & & \\
\hline $\mathrm{df}$ & 6 & & & \\
\hline \multicolumn{5}{|l|}{ Variable statistics - no shift } \\
\hline Intercept & 2.4 & 0.11 & 211.25 & $<0.0001^{*}$ \\
\hline F1: chl a variables & -0.47 & 0.11 & 23.63 & $<0.0001^{*}$ \\
\hline F2: rainfall variables & -0.16 & 0.12 & 1.95 & 0.1626 \\
\hline F3: SSH variables and temperature standard deviation & 0.12 & 0.07 & 2.6 & 0.1072 \\
\hline F4: SST variables and ONI & 0.3 & 0.1 & 8.76 & $0.0031^{*}$ \\
\hline Season - Spring & -0.26 & 0.17 & 2.576 & 0.1086 \\
\hline Season - Summer & 0.82 & 0.12 & 54.03 & $<0.0001^{*}$ \\
\hline \multicolumn{5}{|l|}{ (B) Model statistics - shifted 2 mo } \\
\hline Negative log likelihood - full model & 53.78 & & & \\
\hline Negative log likelihood - reduced model & 109.27 & & & \\
\hline Pseudo $\mathrm{R}^{2}$ & 0.51 & & & \\
\hline$\chi^{2}$ & 126.575 & & & \\
\hline $\mathrm{p}$ & $<0.0001$ & & & \\
\hline df & 6 & & & \\
\hline \multicolumn{5}{|l|}{ Variable statistics - shifted 2 mo } \\
\hline Intercept & 2.45 & 0.12 & 187.87 & $<0.0001^{*}$ \\
\hline F1: chl a variables & -0.36 & 0.12 & 11.54 & $0.0007^{*}$ \\
\hline F2: rainfall variables & -0.12 & 0.11 & 1.28 & 0.2582 \\
\hline F3: SSH variables and temperature standard deviation & 0.22 & 0.09 & 6 & $0.0143^{*}$ \\
\hline F4: SST variables and ONI & 0.24 & 0.11 & 5.44 & $0.0196^{*}$ \\
\hline Season - Spring & -0.12 & 0.19 & 0.42 & 0.5183 \\
\hline Season - Summer & 0.95 & 0.13 & 62.52 & $<0.0001^{*}$ \\
\hline
\end{tabular}

accumulate in the lee of headlands, including these areas in networks of marine reserves can enhance recruitment-limited adult populations (Mace \& Morgan 2006). Possible future work could include targeted sampling studies of fish larvae off the Kona coast to determine the extent to which they are entrained in eddies and subsequently return to reef habitats. Increased recruitment has been suggested in prior studies (Lobel \& Robinson 1988, Williams \& English 1992, Franco et al. 2006), although we found no evidence that mesoscale eddies were more likely to occur or be absent during months of peak recruitment, and previous findings to that effect (Lobel 1989) did not take into account any measure of sam- pling effort (the number of cruises or days at sea; Fig. 6).

The absence of definitive evidence of linked physical-biological processes in recruitment of new fishes in West Hawai'i supports the need for precautionary management of fish stocks, including the FRAs as established. Furthermore, existing data are clear: West Hawai'i FRAs are enhancing populations of Zebrasoma flavescens as well as the commercial fishery, demonstrating that conservation and protection of marine areas can help ensure sustainability and productivity of stocks (Tissot et al. 2004, Ortiz \& Tissot 2008, Williams et al. 2009). 

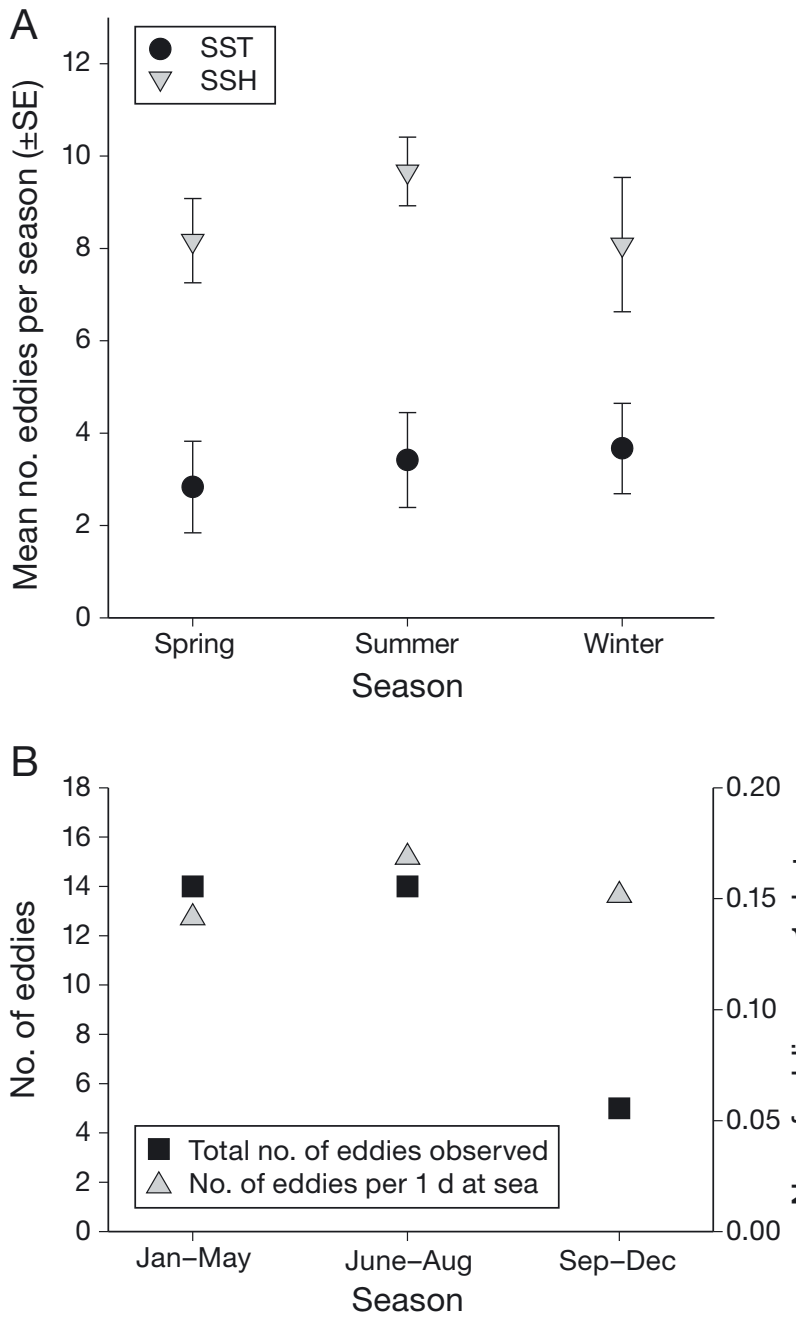

Fig. 6. (A) Mean number of eddy weeks per season for years 1999-2010 determined using satellite images displaying sea surface height ( $\mathrm{SSH}_{;}$Aviso) and sea surface temperature (SST; Pathfinder). Wilcoxon test of eddies by season, 1999-2010, SSH: $\chi^{2}=0.1 .78, \mathrm{p}=0.41, \mathrm{df}=2$; SST: $\chi^{2}=0.51$, $\mathrm{p}=0.78, \mathrm{df}=2$. (B) Reanalysis of data from Patzert (1969) as reported in Lobel (1989). When accounting for days at sea, eddy presence does not coincide with the peak season of recruitment (Wilcoxon test of Patzert 1969 data reanalysis: $\chi^{2}=$

$$
0.19, \mathrm{p}=0.91, \mathrm{df}=2 \text { ) }
$$

Acknowledgements. We are grateful to Evan Howell and Lucas Moxey for providing NOAA CoastWatch data and Kevin Kodama for providing National Weather Service rainfall data. This work was supported by the David $\mathrm{H}$. Smith Conservation Research Fellowship Program, WWF and NOAA's Ecosystems and Oceanography Division. Three anonymous reviewers provided helpful comments on this manuscript. We also thank Jeff Polovina, Raleigh Hood and Don Macanlalay for assistance, and Robin Naidoo and Louise Glew for statistical consultation. Lastly, we acknowledge West Hawai'i fishermen Jim and Jay Lovell for bringing the ONI-fish recruitment relationship to our attention.

\section{LITERATURE CITED}

Balch T, Hatcher BG, Scheibling RE (1999) A major settlement event associated with minor meteorologic and oceanographic fluctuations. Can J Zool 77:1657-1662

Bidigare RR, Benitez-Nelson C, Leonard CL, Quay PD, Parsons ML, Foley DG, Seki MP (2003) Influence of a cyclonic eddy on microheterotroph biomass and carbon export in the lee of Hawaii. Geophys Res Lett 30:1318, doi:10.1029/2002GL016393

Broitman BR, Blanchette CA, Menge BA, Lubchenco J and others (2008) Spatial and temporal patterns of invertebrate recruitment along the West Coast of the United States. Ecol Monogr 78:403-421

> Burgess SC, Kingsford MJ, Black KP (2007) Influence of tidal eddies and wind on the distribution of presettlement fishes around One Tree Island, Great Barrier Reef. Mar Ecol Prog Ser 341:233-242

Bushnell ME, Claisse JT, Laidley CW (2010) Lunar and seasonal patterns in fecundity of an indeterminate, multiplespawning surgeonfish, the yellow tang Zebrasoma flavescens. J Fish Biol 76:1343-1361

Calil PHR, Richards KJ, Jia YL, Bidigare RR (2008) Eddy activity in the lee of the Hawaiian Islands. Deep-Sea Res II 55:1179-1194

Cao GX, Giambelluca TW, Stevens DE, Schroeder TA (2007) Inversion variability in the Hawaiian trade wind regime. J Clim 20:1145-1160

Caselle JE, Warner RR (1996) Variability in recruitment of coral reef fishes: the importance of habitat at two spatial scales. Ecology 77:2488-2504

Cheal AJ, Delean S, Sweatman H, Thompson AA (2007) Spatial synchrony in coral reef fish populations and the influence of climate. Ecology 88:158-169

Chu PS, Wang JX (1997) Tropical cyclone occurrences in the vicinity of Hawaii: Are the differences between El Nino and non-El Nino years significant? J Clim 10:2683-2689

> Claisse JT, McTee SA, Parrish JD (2009) Effects of age, size, and density on natural survival for an important coral reef fishery species, yellow tang, Zebrasoma flavescens. Coral Reefs 28:95-105

> D'Alimonte D (2009) Detection of mesoscale eddy-related structures through iso-SST patterns. IEEE Geosci Remote Sens Lett 6:189-193

Danilowicz BS (1997) A potential mechanism for episodic recruitment of a coral reef fish. Ecology 78:1415-1423

de Souza RB, Mata MM, Garcia CAE, Kampel M, Oliveira EN, Lorenzzetti JA (2006) Multi- sensor satellite and in situ measurements of a warm core ocean eddy south of the Brazil-Malvinas Confluence region. Remote Sens Environ 100:52-66

> Dickey TD, Nencioli F, Kuwahara VS, Leonard C and others (2008) Physical and bio-optical observations of oceanic cyclones west of the island of Hawai'i. Deep-Sea Res II 55:1195-1217

Eble JA, Toonen RJ, Bowen BW (2009) Endemism and dispersal: comparative phylogeography of three surgeonfishes across the Hawaiian Archipelago. Mar Biol 156: 689-698

Fisher R (2005) Swimming speeds of larval coral reef fishes: impacts on self-recruitment and dispersal. Mar Ecol Prog Ser 285:223-232

Flament P, Kennan S, Lumpkin R, Sawyer M, Stroup ED (1996) Ocean atlas of Hawai'i: regional processes. University of Hawaii, Honolulu, HI 
Franco BC, Muelbert JH, Mata MM (2006) Mesoscale physical processes and the distribution and composition of ichthyoplankton on the southern Brazilian shelf break. Fish Oceanogr 15:37-43

Friedlander AM, Parrish JD (1998) Temporal dynamics of fish communities on an exposed shoreline in Hawaii. Environ Biol Fishes 53:1-18

Fu LL, Chelton DB, Le Traon PY, Morrow R (2010) Eddy dynamics from satellite altimetry. Oceanography 23:14-25

> Hunt HL, Scheibling RE (1997) Role of early post-settlement mortality in recruitment of benthic marine invertebrates. Mar Ecol Prog Ser 155:269-301

Jones RS (1968) Ecological relationships in Hawaiian and Johnston Island Acanthuridae (surgeonfishes). Micronesica 4:309-361

Kahru M, Mitchell BG (2000) Influence of the 1997-98 El Nino on the surface chlorophyll in the California Current. Geophys Res Lett 27:2937-2940

Kasai A, Kimura S, Nakata H, Okazaki Y (2002) Entrainment of coastal water into a frontal eddy of the Kuroshio and its biological significance. J Mar Syst 37:185-198

Kilpatrick KA, Podesta GP, Evans R (2001) Overview of the NOAA/NASA advanced very high resolution radiometer Pathfinder algorithm for sea surface temperature and associated matchup database. J Geophys Res Oceans 106: 9179-9197

Kuwahara VS, Nencioli F, Dickey TD, Rii YM, Bidigare RR (2008) Physical dynamics and biological implications of Cyclone Noah in the lee of Hawai'i during E-Flux I. Deep-Sea Res II 55:1231-1251

> Landry MR, Brown SL, Rii YM, Selph KE, Bidigare RR, Yang EJ, Simmons MP (2008) Depth-stratified phytoplankton dynamics in Cyclone Opal, a subtropical mesoscale eddy. Deep-Sea Res II 55:1348-1359

Lehodey P, Alheit J, Barange M, Baumgartner T and others (2006) Climate variability, fish, and fisheries. J Clim 19: 5009-5030

> Leis JM, Carson-Ewart BM (2003) Orientation of pelagic larvae of coral-reef fishes in the ocean. Mar Ecol Prog Ser 252:239-253

Limouzy-Paris CB, Graber HC, Jones DL, Roepke AW, Richards WJ (1997) Translocation of larval coral reef fishes via sub-mesoscale spin-off eddies from the Florida Current. Bull Mar Sci 60:966-983

> Lo-Yat A, Simpson SD, Meekan M, Lecchini DD, Martinez E, Galzin R (2011) Extreme climatic events reduce ocean productivity and larval supply in a tropical reef ecosystem. Glob Change Biol 17:1695-1702

Lobel PS (1989) Ocean current variability and the spawning season of Hawaiian reef fishes. Environ Biol Fishes 24: 161-171

Lobel PS (2011) Transport of reef lizardfish larvae by an ocean eddy in Hawaiian waters. Dyn Atmos Oceans 52: $119-130$

Lobel PS, Robinson AR (1983) Reef fishes at sea: ocean currents and the advection of larvae. In: Reaka M (ed) Workshop on coral reef ecology. US Department of Commerce, Philadelphia, PA, p 29-38

Lobel PS, Robinson AR (1986) Transport and entrapment of fish larvae by ocean mesoscale eddies and current in Hawaiian waters. Deep-Sea Res 33:483-500

Lobel PS, Robinson AR (1988) Larval Fishes and Zooplankton in a Cyclonic Eddy in Hawaiian Waters. J Plankton Res 10:1209-1223

Lumpkin CF (1998) Eddies and currents of the Hawaiian
Islands. PhD thesis, University of Hawaii at Manoa, HI

Mace AJ, Morgan SG (2006) Larval accumulation in the lee of a small headland: implications for the design of marine reserves. Mar Ecol Prog Ser 318:19-29

> Mahaffey C, Benitez-Nelson CR, Bidigare RR, Rii Y, Karl DM (2008) Nitrogen dynamics within a wind-driven eddy. Deep-Sea Res Part II 55:1398-1411

Meekan MG, Ackerman JL, Wellington GM (2001) Demography and age structures of coral reef damselfishes in the tropical eastern Pacific Ocean. Mar Ecol Prog Ser 212: 223-232

> Miller-Sims VC, Atema J, Gerlach G, Kingsford MJ (2011) How stable are the reef odor preferences of settling reef fish larvae? Mar Freshw Behav Physiol 44:133-141

> Nakata H, Kimura S, Okazaki Y, Kasai A (2000) Implications of meso-scale eddies caused by frontal disturbances of the Kuroshio Current for anchovy recruitment. ICES J Mar Sci 57:143-151

Ortiz DM, Tissot BN (2008) Ontogenetic patterns of habitat use by reef-fish in a marine protected area network: a multi-scaled remote sensing and in situ approach. Mar Ecol Prog Ser 365:217-232

> Park JY, Kug JS, Park J, Yeh SW, Jang CJ (2011) Variability of chlorophyll associated with El Niño-Southern Oscillation and its possible biological feedback in the equatorial Pacific. J Geophys Res 116:C10001, doi:10.1029/2011JC 007056

Patzert W (1969) Eddies in Hawaiian waters. University of Hawaii, Hawaii Institute of Geophysics, Honolulu, HI

> Platt T, Fuentes-Yaco C, Frank KT (2003) Spring algal bloom and larval fish survival. Nature 423:398-399

Polovina JJ, Howell EA (2005) Ecosystem indicators derived from satellite remotely sensed oceanographic data for the North Pacific. ICES J Mar Sci 62:319-327

Polovina JJ, Howell E, Kobayashi DR, Seki MP (2001) The transition zone chlorophyll front, a dynamic global feature defining migration and forage habitat for marine resources. Prog Oceanogr 49:469-483

Radford CA, Tindle CT, Montgomery JC, Jeffs AG (2011) Modelling a reef as an extended sound source increases the predicted range at which reef noise may be heard by fish larvae. Mar Ecol Prog Ser 438:167-174

> Rii YM, Brown SL, Nencioli F, Kuwahara V, Dickey T, Karl DM, Bidigare RR (2008) The transient oasis: nutrientphytoplankton dynamics and particle export in Hawaiian lee cyclones. Deep-Sea Res II 55:1275-1290

Seki MP, Polovina JJ, Brainard RE, Bidigare RR, Leonard CL, Foley DG (2001) Biological enhancement at cyclonic eddies tracked with GOES thermal imagery in Hawaiian waters. Geophys Res Lett 28:1583-1586

> Seki MP, Lumpkin R, Flament P (2002) Hawaii cyclonic eddies and blue marlin catches: the case study of the 1995 Hawaiian International Billfish Tournament. J Oceanogr 58:739-745

Shima JS, Swearer SE (2009) Spatially variable larval histories may shape recruitment rates of a temperate reef fish. Mar Ecol Prog Ser 394:223-229

> Sponaugle S, Grorud-Covert K (2006) Environmental variability, early life-history traits, and survival of new coral reef fish recruits. Integr Comp Biol 46:623-633

> Sponaugle S, Pinkard D (2004) Lunar cyclic population replenishment of a coral reef fish: shifting patterns following oceanic events. Mar Ecol Prog Ser 267:267-280

Thresher RE, Colin PL, Bell LJ (1989) Planktonic duration, distribution and population structure of Western and 
Central Pacific damselfishes (Pomacentridae). Copeia 1989:420-434

Tissot BN, Walsh WJ, Hallacher LE (2004) Evaluating effectiveness of a marine protected area network in West Hawaii to increase productivity of an aquarium fishery. Pac Sci 58:175-188

Tissot BN, Walsh WJ, Hixon MA (2009) Hawaiian Islands marine ecosystem case study: ecosystem- and communitybased management in Hawaii. Coast Manage 37:255-273

> Victor BC (1986) Duration of the planktonic larval stage of 100 species of Pacific and Atlantic wrasses (Family Labridae). Mar Biol 90:317-326

Walsh WJ (1987) Patterns of recruitment and spawning in Hawaiian [USA] reef fishes. Environ Biol Fishes 18: $257-276$

Editorial responsibility: Charles Birkeland,

Honolulu, Hawaii, USA
Williams DM, English S (1992) Distribution of fish larvae around a coral-reef - direct detection of a mesoscale, multispecific patch. Cont Shelf Res 12:923-937

Williams ID, Walsh WJ, Claisse JT, Tissot BN, Stamoulis KA (2009) Impacts of a Hawaiian marine protected area network on the abundance and fishery sustainability of the yellow tang, Zebrasoma flavescens. Biol Conserv 142: 1066-1073

Wolanski E, Spagnol S (2000) Sticky waters in the Great Barrier Reef. Estuar Coast Shelf Sci 50:27-32

Worm B, Hilborn R, Baum JK, Branch TA and others (2009) Rebuilding Global Fisheries. Science 325:578-585

Wright KJ, Higgs DM, Cato DH, Leis JM (2010) Auditory sensitivity in settlement-stage larvae of coral reef fishes. Coral Reefs 29:235-243

Submitted: January 27, 2012; Accepted: May 22, 2012 Proofs received from author(s): August 21, 2012 